\title{
XXVI. Note on a Variety of Segetia Xanthographa. XIV. fig. 1.) By J. W. Douglas, Esq.
}

[Read 6th March, 1848.]

$A_{\mathrm{T}}$ the meeting of this Society on November 1st, 1847, I exhibited a most curious specimen of this moth, taken near Manchester, and sent to me by Mr. Edleston. On the right side the wings present the usual appearance of the species, but on the left the upper wing has only a broad stripe of brown on the costal portion, the rest of it being luteous, with a few dark marks, and the lower wing being dark, with a broad luteous dash running down the centre. It is a most singular deviation from the normal appearance of this moth, and has been most ably drawn by Mr. Wing, to whose figure I beg a reference, as giving a better idea of the insect than any description I can make.

What may have been the cause of this variation I am unable to say decisively, but some observations reported to the Entomological Society of France by M. A. Pierret,* will, I think, throw some light on it. He says, that of several species of Lepidoptera which ordinarily have the wings red, varieties occur in which that colour is replaced by yellow. He instances Sphinx Dahlii, $S$. Euphorbia, Zygæra Achillea, Z. Fausta, and Z. Onobrychis, Euchelia Jacobece, Chelonia Caja, C. Hebe, and C. purpurea, Callimorpha Hera and C. dominula. He says the reverse of this never takes place, with the single exception of Callimorpha donna, in which the yellow of the under wings is sometimes replaced by red; but in this case he thinks, that as $C$. donna is really only a variety of $C$. dominula, the apparently accidental red is properly a return to the typical colour. He then concludes, that every yellow variety of a red type is caused by an arrest of the elaboration of the colouring matter of the perfect insect, resulting either from the imperfect or improper nutrition of the caterpillar, or from the influence of atmospheric agents while in the pupa state.

I think that if this theory be correct, that it may account for the variation of the species now before us, although this differs from the examples quoted by M. Pierret, inasmuch as the typical colour is not red, and the yellow variation is on one side only.

* Annales de la Société Entomologique de France, 1847. Tome 5, Bulletin, page lxxii. 


\section{$2 \mathrm{BHL}$ Biodiversity Heritage Library}

1848. "XXVI. Note on a Variety of Segetia Xanthographa. (PI. XIV. fig. 1.) By J.

W. Douglas, Esq." Transactions of the Entomological Society of London 5, 99-99. https://doi.org/10.1111/j.1365-2311.1848.tb01706.x.

View This Item Online: $\underline{\text { https://www.biodiversitylibrary.org/item/51010 }}$

DOI: https://doi.org/10.1111/j.1365-2311.1848.tb01706.x

Permalink: https://www.biodiversitylibrary.org/partpdf/38516

\section{Holding Institution}

Smithsonian Libraries

\section{Sponsored by}

Smithsonian

\section{Copyright \& Reuse}

Copyright Status: Public domain. The BHL considers that this work is no longer under copyright protection.

This document was created from content at the Biodiversity Heritage Library, the world's largest open access digital library for biodiversity literature and archives. Visit BHL at https://www.biodiversitylibrary.org. 